\author{
TECHNO: JURNAL PENELITIAN \\ Jurnal homepage: http://ejournal.unkhair.ac.id/index.php/Techno \\ Volume 06 Nomor 02 Oktober 2017
}

\title{
Kerapatan Mangrove dan Konservasinya di Bacan Kabupaten Halmahera Selatan Provinsi Maluku Utara
}

\author{
Abdulrasyid Tolangara ${ }^{1}$ dan Hasna Ahmad ${ }^{2}$ \\ 1, 2Pendidikan Biologi, Universitas Khairun, Ternate \\ *Corresponding authors: e-mail: rtolangara@yahoo.com \\ Manuscript received: 17-07-2017 Revision accepted: 02--09-2017
}

\begin{abstract}
Abstrak
Hutan mangrove merupakan perpaduan antara dua habitat yaitu terrestrial dan aquatik. Dalam perkembangannya ekosistem ini selalu mengalami kerusakan, ini terjadi kerena belum ada perhatian pemerintah untuk mencegahnya. Metode penelitian ini adalah deskriptif kuantitatif, dengan menggunakan model Point Centered Quarter dan pengambilan sampel dengan menggunakan garis transek serta plot hitung berukuran $10 \mathrm{mx} 10 \mathrm{~m}$ untuk pengamatan tingkat pohon. Mangrove yang diukur pada 2 kawasan yaitu kawasan mangrove alami (A) yang teridiri empat stasiun dan kawasan mangrove rehabilitasi (B) juga terdapat empat stasiun. Pohon yang dipilih adalah pohon yang paling dekat di setiap quarter. Data pengamatan kemudian dianalisis secara kuantitatif berupa kerapatan jenis mangrove di setiap stasiun. Hasil penelitian menunjukkan bahwa kerapatan jenis mangrove kawasan alami berada pada kategori jarang misalnya stasiun I pada jenis A. alba 512 individu $/ \mathrm{m}^{2}$, stasiun II terdapat pada jenis $S$. alba 456 individu $/ \mathrm{m}^{2}$ dan stasiun III pada jenis $R$. apiculata 326 individu $/ \mathrm{m}^{2}$. Sedangkan pada kawasan rehabilitasi berada pada kategori padat hingga sedang, misalnya pada stasiun IV kategori padat yaitu jenis B. gymnorrhiza 3.400 individu $/ \mathrm{m}^{2}$, stasiun I kategori padat jenis $R$. apiculata 2.100 individu/ $\mathrm{m}^{2}$, dan stasiun II kategori padat terdapat pada jenis jenis $R$. stylosa dan stasiun III kategori sedang terdapat pada jenis $R$. mucronata 1.324 individu $/ \mathrm{m}^{2}$. Ini terjadi akibat aktifitas masyarakat yang selalu memanfaatkan potensi hutan tersebut, tanpa upaya konservasi, maka diperlukan upaya konservasi dengan model pengelolaan yang berbasis masyarakat (Community Based Management).
\end{abstract}

Kata Kunci: Mangrove, Kerapatan, Konservasi, Bacan.

\begin{abstract}
Mangrove forest is a combination of two habitats, terrestrial and aquatic. In its development, the ecosystem experiences damage due to the less attention from the government to prevent it. Therefore, information is needed to find out about the comparison of density between natural and rehabilitation areas. The research method used was quantitative descriptive using Point Centered Quarter model and sampling used was transect line with calculation plot in size of $10 \mathrm{~m} \times 10 \mathrm{~m}$ for observation of tree stage. Mangrove was measured in two areas, natural mangrove (A) and rehabilitation mangrove (B) both consisted of four stations. Trees chosen were the closest trees in each quarter. Observation data was analyzed quantitatively in form of the density of mangrove type in each station. The research result indicates that the density of mangrove type in natural area was in sparse category, such as in Station I for type of A. Alba the density was 512 individual $/ \mathrm{m}^{2}$, Station II with type of $S$. alba was 456 individual $/ \mathrm{m}^{2}$ and Station III in type of R. apiculata was 326 individual $/ \mathrm{m}^{2}$. In rehabilitation area, on the other hand, was in dense to moderate category, such as the dense category in Station IV was for type of B. gymnorrhiza of 3,400 individual $/ \mathrm{m}^{2}$, Station I was for type of $R$. apiculata of 2,100 individual $/ \mathrm{m}^{2}$, and Station II was for $R$. stylosa. Whereas, for moderate category in Station III was in $R$. mucronata of 1,324 individual $/ \mathrm{m}^{2}$. It was due to the activity of the community that utilized the forest potential without conservation effort. Therefore, a conservation effort is needed through community based management model.
\end{abstract}

Keywords: Mangrove, Density, Conservation, Bacan. 


\section{PENDAHULUAN}

Mangrove berasal dari perpaduan bahasa Portugis "Mangue" dan bahasa Inggris "grove" (Macnae, 1968 dalam Noor dkk, 2006). Kata mangrove berasal dari bahasa melayu kuno "mangimangi "yang menunjukkan marga Aveccennia (Mastaller, 1997 dalam Noor dkk, 2006). Maka dapat diartikan bahwa mangrove adalah kumpulan berbagai jenis tumbuhan yang hidup di daearah pasang surut air laut (intertidal), yang memiliki kemampuan untuk beradaptasi dengan kondisi salinitas yang tinggi, substrat berragam serta lama peggenangan yang bervariasi.

Hutan mangrove merupakan perpaduan antara dua habitat yaitu terrestrial dan aquatik. Perpaduan ini menjadikan ekosistem hutan mangrove memiliki karakteristik khas, baik ditinjau dari segi fisiografi maupun keragaman biota yang terintegrasi dalam ekosistem mangrove. Karakteristik ini akan lebih unik lagi karena adanya perpaduan budaya masyarakat yang hidup di sekitarnya, sebagai komponen ekosistem yang saling berinteraksi secara alami dan saling mendukung secara serasi dan seimbang. Keserasian hubungan antara komponen alamiah inilah yang akan membentuk kekhasan suatu ekosistem. Ekosistem alami yang telah mencapai keseimbangan ini selalu bersifat dinamis dan tingkat kedinamisannya berbeda antara satu ekosistem dengan ekosistem lainnya (Dahuri dkk, 2003).

Ekosistem hutan mangrove dikenal sebagai ekosistem yang paling dinamis dan sangat rentan terhadap perubahan lingkungan. Hal ini secara ekologis dapat terjadi karena dua ekosistem yang secara fisik berbeda dalam berinteraksinya dan selalu kompleks, sebagai pencirinya adalah selalu dipengaruhi oleh pasang surut air laut. Oleh karena itu ekosistem hutan mangrove mempunyai arti dan fungsi yang strategis baik ditinjau dari segi ekologis maupun sosial ekonomi dan budaya masyarakat (Arief A, 2003).

Kusmana C. dkk, (2003) menjelaskan bahwa hutan mangrove dalam posisinya sebagai sistem sumberdaya pesisir memiliki fungsi ekologis dan ekonomis yang sangat bermanfaat bagi manusia serta berperan sebagai salah satu bafer untuk melindungi garis pantai. Hutan mangrove pada perkembangannya mengalami suatu proses perluasan maupun degradasi. Ini terjadi karena kurangnya kesadaran dari masyarakat, mengakibatkan ekosistem hutan mangrove dimanfaatkan untuk berbagai kepentingan yang kurang bijaksana. Sehingga menyebabkan tingkat kerusakan hutan mangrove jauh lebih cepat dibandingkan dengan kemampuan rehabilitasinya.

Pulau Bacan, sebagai salah satu kawasan ada di Kabupaten Halmahera Selatan Provinsi Maluku Utara yang memiliki ekositem hutan mangrove yang secara alami telah membentuk interaksi yang kompleks dan unik dengan kekhasan kehidupan masyarakat sekitarnya. Dilihat dari berbagai aktifitas masyarakat lokal maupun swasta, hutan mangrove di kawasan ini dimanfaatkan sebagai basis kegiatan ekonomi. Diantaranya sebagai daerah penangkapan ikan, udang, kepiting serta aktifitas lainnya. Proses pemanfaatan yang berpotensi mengancam kelestarian ekosistem hutan mangrove adalah penebangan yang berlebihan. Aktifitas ini dilakukan sejalan dengan pertumbuhan penduduk dan perluasan pemukiman masyarakat yang sebagian besar memanfaatkan kayu mangrove untuk kebutuhan konstruksi serta bahan kayu bakar.

Aktifitas masyarakat (faktor antropogenik) ini terus meningkat sejalan dengan mobilitas penduduk serta kebutuhannya yang makin tinggi sebagai akibat dari pengembangan kawasan ini menjadi sentral kabupaten, sementara ketersediaan sumberdaya hutan mangrove semakin terbatas. Kondisi ini lebih dikhawatirkan kerena belum ada perhatian pemerintah untuk mencegahnya, sehingga dapat menimbulkan berbagai ancaman degradasi habitat dan kerapatan jenis mangrove di daerah tersebut. Untuk menghindari kemungkinan perluasan dampak dan degradasi hutan mangrove serta mempertahankan keberadaannya, maka diperlukan suatu perencanaan dan pengelolaan secara berkelanjutan. Sehingga dibutuhkan informasi dasar 
mengenai perbandingan kerapatan antara kawasan mangrove alami dan kawasan mangrove rahabilitas, dengan informasi ini diharapkan menjadi acuan untuk pengeloalan kawasan konservasi hutan mangrove di Pulau Bacan.

\section{METODE PENELITIAN}

Metode penelitian ini adalah deskriptif, yang pengambilan sampelnya pada masing-masing sub stasiun dengan menggunakan garis transek dan plot hitung berukuran $10 \mathrm{~m} \times 10 \mathrm{~m}$ untuk pengamatan tingkat pohon.

\section{Cara pengambilan data}

Dalam menghitung jumlah individu mangrove pada tiap tegakan pohon, maka dilakukan dengan menggunakan metode Point Centered Quarter (Mitchell K, 2001) di setiap sub stasiun. Mangrove yang diukur adalah mangrove yang berada di titik Point Centered Quarter yang terdapat pada 2 kawasan yaitu kawasan mangrove alami (A) yang teridiri empat stasiun dan kawasan mangrove rehabilitasi (B) juga terdapat empat stasiun. Pohon yang dipilih adalah pohon yang paling dekat di setiap quarter (Mitchell K, 2001) setelah itu dihitung semua mangrove yang termasuk di dalam plot hitung (data kerapatan jenis) .

Jarak yang diukur untuk pemetaan kerapatan pohon mangrove hanya yang masuk dalam kriteria pohon, yaitu tumbuhan yang memiliki ukuran tinggi $>1 \mathrm{~m}$ dan diameter batang $10 \mathrm{~cm}$ (Fachrul, 2007). Kriteria baku kerapatan pohon dapat dilihat pada Tabel 1.

Tabel 1. Kriteria Baku Kerapatan Pohon

\begin{tabular}{cc}
\hline Kriteria Baku & Kerapatan (pohon/ha) \\
\hline Padat & $\geq 1,500$ \\
Sedang & $\geq 1,000-1,500$ \\
Jarang & $<1,000$ \\
\hline
\end{tabular}

Sumber : Kepmen LH No. 201 tahun 2004

\section{Analisis Data}

Perhitungan besarnya nilai kuantitatif parameter mangrove adalah sebagai berikut :

a. Jarak rata-rata individu pohon ke titik pengukuran

$$
\mathrm{d}=\frac{\mathrm{d} 1+\mathrm{d} 2+\ldots \ldots \ldots \ldots \ldots .+\mathrm{dn}}{\mathrm{n}}
$$

Keterangan : $\mathrm{d}=$ jarak individu pohon ke titik pengukuran disetiap plot hitung

$\mathrm{n}=$ banyaknya pohon

$(d)^{2}=$ adalah rata-rata area/individu, yaitu rata-rata luasan permukaan tanah yang diokupasi oleh satu individu tumbuhan (Setyobudiandi, 2009).

b. Kerapatan Jenis

$$
\mathrm{Di}=\frac{n i}{A}
$$

Keterangan $: \mathrm{Di}=$ kerapatan jenis

$\mathrm{ni}=$ jumlah total tegakan jenis ke-i

$\mathrm{A}=$ luas total area pengambilan contoh (luas petak contoh/plot) (Natan, 2008). 


\section{HASIL DAN PEMBAHASAN}

Berdasarkan hasil pengamatan kerapatan jenis mangrove yang dilakukan pada 2 kawasan yaitu kawasan mangrove alami (A) dan kawasan mangrove rehabilitasi (B) dengan 8 stasiun, yang hasilnya disajikan pada Tabel 2.

Tabel 2. Komposisi dan Kerapatan Jenis Mangrove pada Kawasan Mangrove Alami dan Rehabilitasi

\begin{tabular}{cccc}
\hline No & Stasiun & \multicolumn{1}{c}{ Nama Jenis } & Kerapatan jenis (Di) \\
\hline \multicolumn{2}{l}{ Kawasan Mangrove } & Alami (A) & \\
1 & I & Avicennia alba & 512 \\
2 & II & Sonneratia alba & 456 \\
3 & III & Rhizophora apiculata & 326 \\
4 & IV & Bruguiera gymnorrhiza & 2.100 \\
\hline \multicolumn{2}{l}{ Kawasan Mangrove } & Rehabilitasi (B) \\
\hline 1 & I & Rhizophora apiculata & 2.100 \\
2 & II & Rhizophora stylosa & 1.600 \\
3 & III & Rhizophora mucronata & 1.324 \\
4 & IV & Bruguiera gymnorrhiza & 3.450 \\
\hline
\end{tabular}

Berdasarkan hasil pengukuran kerapatan jenis mangrove pada Tabel 2 tampak bahwa nilai kerapatan jenis tertinggi pada kawasan mangrove alami (A) terdapat pada stasiun IV kategori padat yaitu jenis B.gymnorrhiza 2.100 individu/ $\mathrm{m}^{2}$, stasiun I kategori jarang terdapat pada jenis A. alba 512 individu/ $\mathrm{m}^{2}$, stasiun II kategori jarang terdapat pada jenis $\quad$ S. alba 456 individu $/ \mathrm{m}^{2}$ dan stasiun III kategori jarang pada jenis $R$. apiculata 326 individu/ $\mathrm{m}^{2}$. Sedangkan nilai kerapatan jenis tertinggi pada kawasan mangrove rehabilitasi (B) terdapat pada stasiun IV kategori padat yaitu pada jenis B. gymnorrhiza 3.400 individu/ $\mathrm{m}^{2}$, stasiun I kategori padat pada jenis $R$. apiculata 2.100 individu/ $\mathrm{m}^{2}$, stasiun II kategori padat terdapat pada jenis jenis $R$. stylosa dan stasiun III kategori sedang terdapat pada jenis $R$. mucronata 1.324 individu/ $\mathrm{m}^{2}$.

Pada kawasan mangrove alami (A) di setiap stasiun pengamatan menunjukkan kerapatan jenis mangrove kategori padat terdapat pada stasiun IV, sementara stasiun I, II dan III kategori jarang. Hal ini dapat terjadi karena pada kawasan mangrove alami berada di zona depan yang dinamakan dengan mangrove terbuka. Menurut Chyun (2015) bahwa mangrove yang berada pada zona depan yang berhadapan dengan laut, zona ini di dominasi oleh jenis S. alba dan A. alba yang tumbuh pada areal yang benar-benar dipengaruhi oleh pasang surut air laut. S. alba cenderung mendominasi daerah berpasir, sementara Avicennia marina dan Rhizophora mucronata cenderung untuk mendominasi daerah yang berlumpur lembek.

Selain itu, jenis B. gymnorrhiza yang ada pada kawasan mangrove alami (A) memiliki kerapatan jenis paling tinggi (kategori padat), hal ini terjadi karen masyarakat di daerah ini sangat jarang mengambil kayu dari jenis pohon tersebut, dengan alasan bahwa kayu ini bila dibakar cepat menghasilkan abu dan panasnya tidak bertahan lama. Kondisi ini sejalan dengan hasil penelitian FAO (1994) di Sierra Leone dalam Tolangara dan Corebima (2014) yang menyimpulkan bahwa kayu mangrove jenis B. gymorrhiza jarang digunakan sebagai bahan kayu bakar, bila dibanding dengan kayu mangrove jenis R.apiculata, S.alba dan A.alba yang lebih banyak digunakan sebagai bahan kayu bakar untuk mengasap ikan (proses banda). Karena jumlah kayu bakar dalam memproses ini kurang lebih sama dengan berat tubuh ikan, maka tidak heran jika ini menjadi penyebab berkurangnya kerapatan jenis mangrove (kategori jarang) di kawasan mangrove alami (A). Penebangan mangrove untuk kayu bakar telah menjadi pekerjaan utama masyarakat nelayan. Perbandingan kayu bakar dengan berat tubuh ikan untuk 
pengasapan, maka kayu $R$. apiculata akan menghasilkan energi panas yang tinggi sebesar 5, 017 $\mathrm{cal} / \mathrm{gw}$, dan kayu S. alba akan menghasilkan energi panas sebesar 4,012 cal/gw serta kayu jenis A.alba menghasilkan energi panas sebesar 2, $023 \mathrm{cal} / \mathrm{gw}$.

Dijelaskan pula oleh Inoue et al., (1999) dalam Tolangara dan Corebima (2104) bahwa jenis pohon R.apiculata (bakau) merupakan kayu yang berkualitas baik, karena menghasilkan energi panas yang tinggi dan awet. Kayu bakar dari mangrove sangat efisien, karena dengan diamater $8 \mathrm{~cm}$ dan panjang $50 \mathrm{~cm}$ cukup sekali memasak untuk 5 orang. Kayu bakar sangat penting bagi masyarakat terutama dari golongan miskin, ketika harga bahan bakar minyak melambung tinggi. Dengan alasan bahwa kayu mangrove memiliki kemampuan untuk menghasilkan energi panas jauh lebih tinggi bila dibanding dengan kayu lainnya, maka kerusakan hutan mangrove terus terjadi. Kondisi inilah yang membuat masyarakat di sekitar hutan mangrove selalu menebang kayu mangrove guna memenuhi kebutuhan hidup mereka.

Sementara pada kawasan mangrove rehabilitasi (B) di setiap stasiun pengamatan menunjukkan bahwa pada stasiun IV kategori padat yaitu pada jenis B. gymnorrhiza 3.400 individu/ $\mathrm{m}^{2}$, stasiun I kategori padat pada jenis $R$. apiculata 2.100 individu/ $\mathrm{m}^{2}$, stasiun II kategori padat pada jenis jenis $R$. stylosa dan stasiun III kategori sedang terdapat pada jenis $R$. mucronata 1.324 individu $/ \mathrm{m}^{2}$. Hal ini dapat terjadi karena pada kawasan mangrove rehabilitasi ini berada di zona tengah. Menurut Irwanto (2014) bahwa Zona tengah, merupakan kawasan yang terletak di belakang zona garis pantai (zona depan) dan memiliki lumpur liat. Biasanya ditemukan jenis $R$. apiculata, R. stylosa, Avicennia officinalis, Bruguiera cylindrica, B. gymnorrhiza, B. parviflora, B. sexangula, Ceriops tagal, Aegiceras corniculatum, Sonneratia caseolaris dan Lumnitzera littorea.

Bila kerapatan jenis mangrove di kawasan mangrove alami (A) dan kawasan mangrove rehabilitasi (B), dibandingkan maka dapat dikatakan bahwa kerapatan jenis mangrove di lokasi (B) jauh lebih padat mencapai 3.400 individu/ $\mathrm{m}^{2}$, hal ini terjadi karena pada lokasi ini memang sengaja ditanam. Sehingga dengan upaya tersebut jelas bahwa kerapatan jenis mangrove jauh lebih tinggi (lebih padat), maka dengan upaya ini, diharapkan masyarakat yang hidup di sekitar hutan mangrove, agar selalu menjaga, memelihara dan melindungai kawasan rehabilitasi. Ini berarti bahwa masyarakat harus turut berpartisipasi dalam melakukan rehabiltasi kawasan mangrove yang telah mengalami kerusakan.

Sehubungan dengan itu Bengen (2004) mengatakan bahwa meningkatnya pertumbuhan penduduk dan pesatnya kegiatan pembangunan di daerah pesisir untuk berbagai peruntukan (pemukiman, perikanan, pelabuhan dan lain-lain), akan menimbulkan takanan ekologis terhadap ekosistem pesisir, khususnya ekosistem hutan mangrove. Meningkatnya tekanan ini tentunya akan berdampak terhadap kerusakan ekosistem hutan mangrove baik secara langsung (misalnya kegiatan penebangan dan konversi lahan) maupun secara tidak langsung (misalnya pencemaran oleh limbah dari berbagai kegiatan pembangunan). Hal yang sama dijelaskan oleh Saparinto (2007), bahwa kegiatan yang memberikan sumbangan terbesar terhadap kerusakan mangrove di Indonesia terjadi akibat pengambilan kayu untuk keperluan komersil, serta pengalihan peruntukan area mangrove untuk dijadikan lahan tambak dan pertanian.

Menurut Tolangara dan Corebima (2014) bahwa sebagian besar masyarakat yang berada di sekitar hutan mangrove bergantung hidupnya pada kayu dari hutan tersebut. Penggunaan kayu mangrove ini untuk memenuhi kebutuhan hidup mereka diantaranya untuk dijadikan kayu bakar, tiang pagar, tiang rumah, tiang pelabuhan, tiang pengikat perahu, membuat dinding bagian dalam perahu dan lantai perahu, akibat penebangan yang terus-menerus berlangsung, menyebabkan kerapatan jenis mangrove pun menjadi berkurang, karena aktifitas masyarakat 
yang selalu menggunakan kayu mangrove tanpa diimbangi dengan upaya konservasi terhadap jenis tersebut.

Menurut Kusmana (2002) penyebab utama kerusakan hutan mangrove adalah konversi lahan hutan mangrovee untuk budidaya perikanan, lahan pertanian, jalan raya, industri, perkotaan, pertambangan, penggalian pasir dan sebagainya serta penebangan yang berlebihan terhadap kayu mangrove secara legal maupun ilegal untuk produksi kayu bakar, arang dan chip yang telah berlangsung lama. Eksploitasi secara berlebihan ini telah menimbulkan kerusakan dan menurunkan fungsi dan potensi hutan mangrove.

Akibat aktifitas masyarakat tersebut maka saat ini diperlukan suatu tindakan nyata untuk menyelematkan ekosistem hutan mangrove yang telah mengalami kerusakan. Menurut Bengen (2001) terdapat dua konsep utama yang dapat diterapkan yaitu perlindungan hutan mangrove dan rehabilitasi hutan mangrove. Salah satu cara yang dapat dilakukan dalam rangka mengupayakan perlindungan terhadap keberadaan hutan mangrove adalah dengan menunjuk suatu kawasan mangrove untuk menjadi kawasan hutan konservasi, dan suatu bentuk sabuk hijau di sepanjang pantai dan tepi sungai. Bentuk konservasi hutan mangrove seperti ini cukup efektif dilakukan dan membawa hasil, contohnya seperti yang dapat dilihat di Pulau Rambut dan Pulau Dua, Jawa Barat yang telah ditunjuk sebagai suatu kawasan suaka margasatwa (Dahuri, 2001).

Adapun strategi yang digunakan dalam konservasi hutan mangrove adalah dengan melibatkan masyarakat. Karena kegiatan tersebut sangat membutuhkan suatu sifat akomodatif terhadap segenap elemen yang berada di sekitar kawasan mangrove maupun di luar kawasan. Salah satu strategi yang dapat diterapkan dalam konteks konservasi ekosistem hutan mangrove adalah pengelolaan berbasis masyarakat (Community Based Management) (Departemen Kelautan dan Perikanan, 2005). Dahuri (2001) mengemukakan bahwa pengelolaan berbasis masyarakat mengandung arti keterlibatan langsung masyarakat dalam mengelola sumberdaya alam di suatu kawasan. Tujuan mendasar dari pengelolaan ekosistem mangrove adalah untuk meningkatkan konservasi, rehabilitasi dan pemanfaatan berkelanjutan ekosistem mangrove.

\section{SIMPULAN}

1. Kerapatan jenis mangrove pada kawasan alami (A) lebih banyak berada pada kategori jarang misalnya stasiun I pada jenis A. alba 512 individu/ $\mathrm{m}^{2}$, stasiun II terdapat pada jenis S. alba 456 individu $/ \mathrm{m}^{2}$ dan stasiun III pada jenis $R$. apiculata 326 individu/ $\mathrm{m}^{2}$. Sedangkan pada kawasan rehabilitasi (B) lebih banyak berada pada kategori padat hingga sedang, misalnya pada stasiun IV kategori padat yaitu jenis B. gymnorrhiza 3.400 individu/ $\mathrm{m}^{2}$, stasiun I kategori padat jenis $R$. apiculata 2.100 individu/ $\mathrm{m}^{2}$, dan stasiun II kategori padat terdapat pada jenis jenis $R$. stylosa dan stasiun III kategori sedang terdapat pada jenis $R$. mucronata 1.324 individu $/ \mathrm{m}^{2}$. Hal ini dapat terjadi akibat karena aktifitas masyarakat di sekitar kawasan mangrove yang selalu memanfaatkan potensi dari hutan tersebut, dan tanpa diimbangi dengan upaya konservasi.

2. Upaya konservasi terhadap hutan mangrove yang telah mengalami kerusakan adalah dengan model pengelolaan yang berbasis masyarakat (Community Based Management). 
Tolangara dan Ahmad. MANGROVE, KERAPATAN, KONSERVASI, BACAN.

\section{DAFTAR PUSTAKA}

Bengen Dietriech. G. 2001. Pengenalan dan Pengelolaan Ekosistem Mangrove. PKSPL - IPB, Bogor.

Bengen , D.G. 2004. Sinopsis Ekosistem dan Sumber dya Alam Pesisir dan Laut serta Prinsip Pengelolaanya. Bogor: Pusat Kajian Sumber daya Pesisir dan Lautan IPB

BPS Kabupaten Halmahera. 2011. Badan Pusat Statistik Penduduk. (online) (http://www.depdagri.go.id/pages/profil-daerah/kabupaten/id/82/Kabupaten-

Kementerian Dalam Negeri - Republik Indonesia, diakses 5 September 2012)

Dahuri, R; Jacub Rais; Sapta Putra Ginting; M. J. Sitepu. 2008. PengelolaanSumber Daya Wilayah Pesisir dan Lautan secara Terpadu, Cetakan ke empat, Pradnya Paramita. Jakarta

Dahuri, R., J. Rais, S.P. Ginting dan M.J. Sitepu. 2001. Pengelolaan Sumberdaya Wilayah Pesisir dan Lautan secara Terpadu. Pradnya Paramita, Jakarta.

Dahuri, R. 2003. Keaneka Ragaman Hayati Laut : Aset Pembangunan Berkelanjutan Indonesia. Gramedia Pustaka Umum. Jakarta.

Dahuri R. 2001. Penglolaan Sumber Daya Wilayah Pesisir dan Lautan secara terpadu. PT. Pradnya Paramita. Jakarta

FAO. 1994. Mangrove Forest Management Guidelines Fao Forestry Papaer 117. (online) (http://archive.Org/stream/mangroveforestma034845mbp/mang,diakses,5Juni 2013)

Fachrul, Ferianita Melati. 2006. Metode Sampling Bioekologi. Bumi Aksara. Jakarta

Harahab, Nuddin. 2010. Penilaian Ekonomi Ekosistem Hutan Mangrove dan Aplikasinya dalam Perencanaan Wilayah Pesisir. Graha Ilmu. Yogyakarta.

Irwanto. 2014. Hutan Bakau Zonasi Hutan Mangrove. www. irwantoshut.com/hutan_bakau_zonasi mangrove. Html, diakses, 1 Maret 2016

Inoue, Y., O. Hadiyati, H.M. A. Arffendi, K.R. Sudirman dan I.N. Budiana. 1999. Model Pengelaolaan Hutan Mangrove Lestari. Departemen Kehutanan dan Perkebunan dan JICA. Jakarta.

Kementerian Lingkungan Hidup. 2004. Keputusan Menteri Lingkungan Hidup Nomor 51 Tahun 2004 tentang Baku Mutu Air Laut . Jakarta: Kementerian Lingkungan Hidup.

Kementerian Kelautan dan Perikanan. 2005. Keputusan Menteri Kelauatan dan Perikanan Nomor 60 Tahun 2005 tentang Konservasi Sumberdaya Pesisir dan Laut. Jakarta: Kementerian Kelautan dan Perikanan.

Krebs, 1989. Ecological Methodology . Harper Collins Publisher. New York.(online) tersedia www. Krebs-ecological-methodology diakses 24 Juni 2010.

Kusmana, C. 2002. Ekologi Mangrove. Fakultas Kehutanan - IPB Bogor.

Mitchell K. 2001. Quantitative analysis by the Point-centered Quarter methodhttp:// people.hws.edu/mitchell/PCQM.pdf (skripsi Universitas Hasanuddin). Makasar Sulawesi Selatan. 
Natan, Yuliana. 2008. Studi Ekologi dan Reproduksi Populasi Kerang Lumpur Anodontia Edentula pada Ekosistem Mangrove Teluk Ambon Bagian Dalam. Disertasi. Sekolah Pascasarjana Institut Pertanian Bogor.

Noor, R.Y; M. Khazali; I.N.N, Suryapura. 2006. Panduan Pengenalan Mangrove di Indonesia. Wetsland International, Indonesia Programme. Bogor.

Saparinto 2007. Pendayagunaan Ekosistem Mangrove. Dahara Press. Semarang

Setyobudiandi. 2009. Sampling dan Analisis Data Perikanan dan Kelautan: Terapan Metode Pengambilan Contoh di Wilayah Pesisir dan Laut Makaira - FPIK. Bogor

Sidik, F. 2005. Coastal Greenbelt . Balai Riset dan Observasi Kelautan-DKP. Bali

Tolangara, A.R., and A.D. Corebima. 2014. Species Composition and Utilization Patterns of Mangrove in the District of Jailolo West Halmahera Province of North Mollucas. Indonesia. Enviromental Science an Indian Journal. Volume 9 Issue 10. ISSN 0974-7451. pp359-364.

Tolangara, A.R., Hasan Tuaputty and A.D. Corebima. 2015. Comparing Several Mangrove Seedlings. Donnish Journals. Volume 2 (1). ISSN 2014-1162.pp.008-011. February 2015. 